\title{
OBSERVATIONS ON LUTSI ORAL TRADITION
}

\author{
Kristi Salve \\ Estonian Literary Museum, EE \\ kristi.salve@gmail.com
}

\begin{abstract}
This article examines Lutsi intangible culture in an attempt to clarify the origins of this language island. Historical stories about coming from "Sweden" refer to southern Estonia, but such stories are also widespread in areas that were never under Swedish rule. The Christian tradition is based on the church language and literature of Estonia. Lutsi laments or lament-like songs are unique, different from Seto laments, but also from the lament-like orphan songs of southern Estonia. Work songs and ritual songs (tavandilaul) as well as narrative songs are related to traditions found in both Võromaa and Setomaa. Oskar Kallas's documentation contains an impressive number of children's songs and readings, short verses, and other peripheral material. Their proportion only increases in later collections. The influence of Latvian songs is striking and can be seen from direct translations to texts where original and borrowed material intermingle. The Lutsi tradition was also probably influenced by their Slavic neighbours. Comparisons with the folklore of the other South Estonian language islands and that of the Tver Karelians shows both commonalities and differences.
\end{abstract}

Keywords: folklore styles, laments, runic songs, Christian tradition, Finnic, South Estonian, Lutsi, Latvian influence

DOI: https://doi.org/10.12697/jeful.2021.12.2.11

\section{Introduction}

Serious interest in the Lutsis has resurfaced in the 21 st century. Thus far the Lutsi language has been the aspect of their intangible culture to receive the most attention. Language and the oral tradition conveyed through it are closely related and connected in many ways. Written language documentation as well as audio recordings of folk songs, stories, religious and folklore material, historical accounts, and other similar material are the focus of research for folklorists and ethnologists. However, texts collected primarily for their folklore may also hold great interest for linguists. Especially folk songs, but also stories, short forms, 
and other texts preserve archaic words, word combinations, grammatical forms, and other material lost in everyday language. This has allowed us to talk about linguistic archaeology based on Estonian runic songs (Peegel 1970).

1893 can be considered a turning point in the history of Lutsi research. This was the year that a young Estonian folklorist, Oskar Kallas, travelled to the Lutsi villages on an expedition supported by the Finnish Literature Society. He published two books based on this research: Lutsi maarahvas (The Lutsis; Kallas 1894) and Kaheksakümmend Lutsi maarahva muinasjuttu (Eighty Lutsi folk tales; Kallas 1900). The 20th century saw the accelerating and final disappearance of the Lutsi language; a process, which had already begun in the previous century or centuries. At the same time, the amount of collected material continued to increase. In 1911, Finnish linguist Heikki Ojansuu documented Lutsi and the language of the other South Estonian language islands. Paulopriit Voolaine made numerous documentation trips from Estonia and also worked to support Lutsi traditional culture with the help of various research organisations and institutions. August Sang conducted documentation expeditions among the Lutsis for the purpose of linguistic research. There was also interest in Latvia in this minority group: composer and musicologist Emilis Melngailis recorded a number of Lutsi songs. Estonian and Latvian researchers continued their documentation expeditions during the decades of the Soviet occupation and stored these materials in various archives. As noted above, linguistic documentation also offers interesting material for researchers of folklore and ethnology.

Publication and research have proceeded differently depending on the nature of the material. Oskar Kallas's book of folk tales has been republished electronically (Kallas 2008) and in print (Kallas 2015). Stories recorded by Kallas and other researchers (Paulopriit Voolaine, August Sang) have also been published with commentary online (Annom et al. 2011) and in print (Annom et al. 2018); also in Latvian (Godiņš 2015).

Lutsi songs have been published much less than their stories. The Lutsi material, like that collected from the other South Estonian language islands, contains proverbs and riddles, which have appeared in academic publications (Hussar et al. 1980-1988, Krikmann \& Saukas 2001-2014). A large number of several types of folklore texts have 
recently been published in the South Estonian language islands volume of the "Eesti murded" (Estonian dialects) series (Mets et al. 2014). There are also scattered individual texts in various scientific and popular publications.

The following observations on Lutsi folk songs and other elements of intangible culture are based on Oskar Kallas's classic book Lutsi maarahvas (1894). It gives a more or less exhaustive picture of the songs in Lutsi and other elements of oral tradition remembered at the time they were documented. The material collected by later researchers has been used for comparison and supplementation as necessary. Its wider involvement would lead to a number of problems. First of all, it is apparent that some singers were visited repeatedly by different researchers or even the same researcher, but repeated performances by one singer are not equivalent to variations recorded from different singers. Second, especially when comparing material collected in the second half of the 20th century with that from Kallas, there is already a diachronic aspect at play. Over time, there was a significant narrowing of the repertoire, which is linked with the emergence of marginal genres.

In this article, I endeavour to find an answer to the question of what Lutsi oral tradition can tell us about their history. Folk songs are my primary focus, but I also examine other song genres. I will also examine the question: does this material makes it clear(er) when and how the South Estonian language island near the eastern Latvian city of Ludza came into existence? At the same time, the links between runic songs and other traditional forms of singing as well as with other folklore genres and the folk songs of neighbouring nations are also discussed. I will also touch upon the folklore of the other South Estonian language islands (Kraasna and Leivu) through comparisons. It is also sensible to compare the Lutsis with other Finnic language islands. One particular Karelian language island provides the best comparison. These are the Tver Karelians who relocated at a fairly specifically known time and who were already offered as a comparison to the Lutsis by Oskar Kallas. According to Kallas, both groups moved to their new home territories in the 17th century - the Karelians after 1617 following the conclusion of the Treaty of Stolbovo, the Lutsis in the mid-17th century (Kallas 1894: 38). 


\section{Lutsi origins in folklore data}

Oskar Kallas's hypothesis that the Lutsis are descendants of relatively recent immigrants has been mostly confirmed and further developed by linguists for more than a century. However, this question cannot be considered to be completely resolved. In fact, G. Mannteuffel, who in 1868 was one of the first to mention the Lutsis in writing, noted the possibility that the Lutsis had lived in the Ludza area since the beginning (Kallas 1894: 36-37). More recently, Lembit Vaba has been a strong supporter of the same view, while also acknowledging later immigration (Vaba 1997: 33, Vaba 2001). In his opinion, the long survival of the Lutsi language around Ludza is due to a unique balance in conditions there, which are characterised by "etnilise ja konfessionaalse heterogeensuse" (ethnic and confessional heterogeneity) (Vaba 1997: 33-35) or "rahvuste pudru seas" (a porridge of nations) (cf. Kallas 1894: 12). Paul Ariste also suggested - albeit only in passing and without further explanation - the existence of an old Finnic substrate, while at the same time considering the majority of Lutsi ancestors being later immigrants (Ariste 1956).

A generally valid development in Lutsi emigration theories is the view that the Lutsis originated from the Setos. Unexpectedly and directly, Ülo Tedre presented this view in an article about Oskar Kallas's folklore research. Among other things, Tedre gave a rather detailed overview of Lutsi maarahvas noting the large proportion of narrative songs among the folk songs published in the book (in Tedre's opinion, there are 14 types with 36 variants, which corresponds exactly to the number of songs found in Kallas's book in the section entitled "Jutustavad laulud" (Narrative songs); however, there are texts in this section, which clearly do not fit into it). Tedre notes: It seems that the researcher has either asked specifically for narrative songs or these have a place of honour in the repertoire. Taking into account a Seto origin, this [i.e., the inherently high proportion of lyroepics - K.S.] is not impossible. ("Näikse, et koguja on kas küsitlenud eriti jutustavaid laule või on viimased olnud repertuaaris aukohal. Arvestades setu päritolu pole see võimatu", Tedre 1998: 146). This would then be at least the third position on the origin of the Lutsis based on an analysis of folklore.

Ülo Tedre's article, as if accidentally dropping the claim that the Lutsis originate from the Setos, at first only surprised me: on what 
grounds, apart from the relatively large proportion of narrative songs, was this conclusion based, which differed from long-held and generally accepted views? At the same time, I myself am well acquainted with the situation in the field of folk tales where the similarity of Seto and Lutsi is clearly visible, and this is not at all the case in the newer repertoire where the similarity could be explained by common sources for loans. Conversely, the Setos and Lutsis often specifically have more ancient folk tales in common, which may be completely unknown in neighbouring nations. Often such folk tales contain archaic religious concepts as well as frequent song interludes. It should be noted that AT 425A "Üheksa velle sõsar" (The Sister of Nine Brothers; Salve \& Sarv 1987: 14-15, etc.) belongs to this group and also found its way into the Latvian repertoire. The Latvian variants differ considerably from the ones in Lutsi, which shows that we are dealing with a substrate instead of a recent loan. Therefore, I began to understand that Ülo Tedre's observation could still turn out to be a fruitful hypothesis, forcing a different perspective to be critically considered. I will attempt to do this below by analysing the songs with an eye on folklore genre and specific typological units, in order to determine which origin theory they support.

\section{Toponyms and ethnonyms, historical origins}

Arguments in favour of the Lutsis as indigenous are partially sociolinguistic and seem convincing. Good concrete examples of the language situation at the end of the 19th century are already given by Kallas (1894: 11); later researchers, for example Voolaine (1925), offer equally compelling examples. Perhaps influential in this situation was that Lutsi was not the language of state or church, and that it also differed from the language of the surrounding majority, and, indeed, was just one of many different minority groups and as a result was uniquely preserved. Perhaps the real death sentence for the Lutsis (or rather for the Lutsi language, as it was precisely language that distinguished the Lutsis from other Catholics in Latgale) was the elevation of the Latvian and Latgalian languages to a predominant position in the Republic of Latvia.

Oskar Kallas thought that contemporary place names spoke in favour of the Võro origins of the Lutsis. And, indeed, a string of Lutsi 
place names correspond to ones in Võromaa. In addition to toponyms, Kallas also gave considerable attention to ethnonyms in his books on the Lutsi and Kraasna communities (Kallas 1894, Kallas 1903). So, for example, he considered the use of the toponym/ethnonym Rootsi 'Sweden/Swedish' to be an important distinguishing feature between the Lutsi and Kraasna communities. Use of this term by the Lutsis would seem to be evidence that they had lived under Swedish rule in the past, while the absence of this term in Kraasna appears to confirm that its inhabitants came from Setomaa. However, the relevant material is by no means uniform. Thus, in multilingual Latgale, this hypothetical Swedish origin is confirmed by a loanword in Lutsi: Mii olli Shveeda rahvas 'We were people of Sweden' (ERA II 33, $24<$ Lutsi - P. Voolaine (1930)). However, it is clear that this old original name, which all Finnic nations have historically known independent of whether or not they had lived under Swedish rule during a relatively late and brief period of history, had simply been forgotten by the Kraasna community.

There has been a great deal of confusion regarding ethnonyms, including self-designations, in the Lutsi community. It is true (according to linguists) that the use of several self-designations by speakers of one language or the same self-designation by speakers of different languages is a rather common phenomenon among Finnic nations, as shown by Riho Grünthal (1997). Their neighbours also called the Lutsis by various names, including tchuhna (Kallas 1894: 15, 16). For the Lutsis, this term appears to have had no pejorative connotation. This was also the case in the Kraasna community where phonetic variants of this term were used as a self-designation (Kallas 1903: 39). However, it would be interesting to know who the Tsukhna kuning - the Tsukhna king - was for the Lutsis (Kallas 1894: 59). Did he rule Maa pool in Estonia - or over Roodzi maa - Sweden (Kallas 1894: 38)? The meaning of tsukhna would in this case be approximately the same as for the Setos, i.e., 'a Lutheran speaker of our (or almost our) language'. At the very least, it seems like the mishmash of Lutsi ethnonyms does not arise unequivocally from their own multilingualism or from the surrounding Babel of nations (see also Voolaine 1925: 374 et seq.).

An interesting example of defining an ethnic group based on religious affiliation is shown by Lutsi tshiuli, kiuli: phonetic variants of the same word, which refers to Germans as well as Lutheran Estonians and Latvians (Kallas 1894: 30). It is quite remarkable that the very same 
word was known in Kraasna where in the 19th century kivli referred to Estonian-Lutheran immigrants (Kallas 1903: 39-40). In Setomaa, which has been considered the place of origin for the Kraasna community, this word is unknown. What were the possible connections between the Lutsi and Kraasna communities? Could it just be that the name used for a third ethnic group was adopted in casual communication if there was even alienation between Orthodox and Catholic believers? Catholic Lutsis did not consider Orthodox Estonians to be Estonians anymore: Olõ õi nimä Maarahvas, nimä uma Vindlaze! 'They aren't Lutsi, they are Russian!' (Kallas 1894: 49) Of course, ethnicity was also defined in parallel by language.

Voolaine visited the Lutsis in the generation after Kallas encountering an already different political situation. According to Voolaine, terms with a pejorative connotation still in full use at the time were tshiuli (primarily referring to Lutheran Latvians) and tshangali (referring to Catholic Latgalians); however, Catholic Lutsi speakers could also still refer to their Latgalian fellow believers as tshangali (Voolaine 1925: 376-377). Oral history certainly has something to say about the origin of the Lutsis, but at the same time it also remains a type of folklore, and so cannot be taken at face value.

Ending up in one's current home territory due to one's ancestors being prisoners of war or as a result of being sold and living before then as subjects of a different king are recurring motifs in the historical traditions of many nations and ethnic groups. Of course, there have been many such events and, therefore, the line dividing folklore from reality must be determined in each case separately. A good example are the frequently repeated historical accounts of the Swedish period, the Swedish war, the king of Sweden. This does not mean that all of these stories, even those about trees planted by the king of Sweden, his lost boot, or his promise never to return to rule Estonia, should automatically be accepted as true. A similar account of Swedish origins was known (along with other stories) among the Leivus (also known as the Koiva maarahvas 'Gauja Estonians') (Niilus 1935: 374). A very significant parallel is found in Setomaa, which has never been under Swedish rule, but where there nevertheless exists a historical tradition passed down more or less to the present day stating that they originate from "Swedish people" (Remmel 1997: 120, Valk 1996: 62-64). Even more surprising was discovering such a tradition among the Veps (an 
unwritten conversation in 1975 at Peloila cemetery in the Southern Veps territory). In addition to this account, there is also the expected richness and varied nature of Swedish accounts (including self-identification as Swedish people) found among the Votians whose land was indeed ruled by Sweden for a long time (Västrik 1998: 135-137). It can be said that these Swedish stories were common among the peoples living on the southern and eastern shores of the Gulf of Finland. Taking all of this into account, it seems that Oskar Kallas attributed too much meaning to the stories widespread among the Lutsis of how their ancestors had reached their current homeland (Kallas 1894: 37-39).

\section{Religious language and "Jumala laulud" (God songs)}

In the introduction to Lutsi maarahvas, Oskar Kallas made many cultural historical observations, the value of which has only increased with time. It is commendable that Kallas recorded prayer texts and religious song fragments considering these, along with historical accounts, to be important evidence of the origin of the Lutsi people. It seems, however, that Kallas overestimated their value as evidence. For example, the "riismekesed" (scraps) of religious songs (Kallas 1894: 57) are actually folklorised fragments of songs from the Lutheran hymnal and the repertoire of the Moravian Brethren. Thus, there is no reason to doubt their evangelicalism, but this does not prove the existence of church services or religious literature in the Lutsi language in the past. Kallas contrasts the Lutsis with the ancestors of the Kraasna community who did not have these. The Setos, similarly, did not have a liturgy in their own language until Estonia's independence. Though the Setos are known to have been Orthodox since Christianisation, they still were more than happy to learn from their Lutheran neighbours, first and foremost from the repertoire of the Moravian Brethren, but also religious songs from the church hymnal (Salve 1995). In the absence of documentation of how these songs spread to Setomaa, and likewise knowledge about the history of Setomaa, a faulty conclusion could be drawn based on the lengthy religious songs recorded from the Setos, i.e., that they once had been Lutherans. 
One of Kallas's “riismekesed”, namely,

Kes ol ilmale prisvä, präsvä, 'Those who squandered, reveled with strangers,

ilmale sõprust pidämä make friends in the [bad] world.'

was also known in the Seto tradition where the corresponding verses remained as part of an extensive text until the second half of the 20th century in the following form:

Kes ilmaga prisva ja prasva, 'Those who squandered and reveled with strangers,

kes ilmaga sõprust pidava. $\quad$ those make friends in the [bad] world.'

(RKM Mgn 166b - H. Tampere, V. Pino < I. Pino, 64 years old (1959)

These and many other religious verses from the Lutheran-Moravian tradition reached the Seto repertoire in a form different from printed sources. In Seto tradition, this variation continued.

The second fragment on the same page is undoubtedly based on a church hymn that had been in circulation for centuries and was known as "Põrguvalulaul" (The pain of hell song) (the title of this section of the church hymnal (1881, no. 374) - "Põrgo valust" (On the pain of hell) lent its name to the first song of the corresponding part). It is surprising that with his church background, Oskar Kallas did not know this song, the beginning verses of which are:

Oh tulke, inemise,

Oh tulke, vaivalise,

Ja pandke tähele,
'Oh come, people,

Oh come, poor souls,

And mark my words,'

The source of the Lutsi fragment can be identified as verses 5, 10, and 17 of this very long song:

Verse 5, Line 6:

Kui pime org nink põrguhaud. 'When the valley and the grave of hell are dark.' 
Verse 10, Lines 4 and 5:

Ne tõine tõist sääl pesva 'There they beat each other

Nink hammastega kiskva And tear with [their] teeth'

Verse 17, Lines 1 and 2:

Küll kuradi so kiskva 'Devils tear you apart for sure

Ja paigast tõiste viskva And throw [you] from one place to another'

The first editions of the South Estonian church hymnal were published late enough (in 1685 and 1695) that it is simply impossible that these would have ended up in the hands of migrants if their date of emigration is placed in the mid-17th century. If emigration is placed at the beginning of the 18th century, then it would in principle be possible, although not probable. Especially in view of the Seto parallel, it seems more likely that the religious songs Oskar Kallas recorded - and perhaps also others - reached the Lutsis much later with smaller emigrant groups or individual refugees who merged with the earlier existing Lutsi population. Only from the second half of the 19th century were new Estonian settlers able to preserve their Lutheran identity. However, songs learned so recently from the latter would have probably also been better preserved and the informants would have remembered the circumstances of how they learned them.

Despite all his efforts, Oskar Kallas never got to see a single book in Estonian or meet anyone who had seen one (Kallas 1894: 58). The informants who had confirmed their earlier existence, spoke instead of a storied golden age in which books had been printed even in Lutsi, although the language was considered inferior at the time. Influence from new Estonian settlers cannot be ruled out or mixing of what was heard from them with the Lutsis' vanishing memories of their own past. Likewise, Kallas himself mentioned that the Lutsis continued to have occasional contact with Estonia (Kallas 1894: 63) and that some of what was seen or heard there may also have been remembered.

It is also unclear what songs the informant was thinking of who claimed that Jumala laulu' olli inne ka maavärki 'God songs were also in Lutsi earlier' (Kallas 1894: 54). Nor can it be unequivocally concluded from such a short sentence that this refers to a (Lutheran) church hymn. Folklore songs, i.e., runic epic songs, could easily fit under this 
term as well as (Catholic) religious songs orally translated from other languages. Kallas also published one of the latter (Kallas 1894: 57) and though it is clearly a literal translation by the performer, translations of more widely known and sung songs may have existed earlier.

Some Catholic Lutsi prayers, especially the prayer from Salnigi, less so the morning prayer recorded in Vähä, are clearly reminiscent of Orthodox Seto prayers (see for example the prayers recorded from Anne Vabarna: Kalkun 2001: 59-64). Andreas Kalkun has called such prayers Orthodox, contrasting them with Protestant-Pietist prayers. However, in the case of such non-canonical, folk prayers, the question concerning to which denomination their transmitters belonged is usually not relevant. Tradition bearers were not aware of doctrinal differences among Christian denominations and, moreover, folk prayers could contain non-Christian folk religious elements. Thus, Seto prayers are no more Orthodox than Lutsi prayers are Catholic, as it is not possible to identify Christian elements by denomination, for example, in prayers of the Kraasna community or in the Võro piksepalve 'Thunder's Prayer' of Jürgen of Vihtla. It would be more fitting to characterise all of these as folk tradition or old-fashioned. This folk prayer tradition did not disappear among the Lutsis for at least another generation. Paulopriit Voolaine still recorded this short prayer:

$\begin{array}{ll}\text { Hoia', Jummal, äkilidze surma iist, } & \begin{array}{l}\text { 'Protect [me] God from } \\ \text { sudden death, } \\ \text { tiiulda tõbõ iist! }\end{array} \\ \text { from unexpected disease!' }\end{array}$

ERA II 33, 45 (7)

He also documented Christian motifs grounded in alliteration and parallelism in Lutsi healing prayers (for example, Jeesus Kristus, tuló' sa abist, astu armust! 'Jesus Christ, come and help, have mercy on me!' (ERA 33, 63/4 (16)). The wording of a Seto prayer very directly matches with that of another Lutsi prayer fragment he recorded, which seeks to place

hüva sõna suuhtõ, tarka meelt pääha 'a good word in [my] mouth, a wise mind in [my] head' (ERA II 42, 467 (49)). 
"Ave Maria" is, of course, clearly a Catholic prayer. Perhaps because of its fragmentary nature, Kallas thought it possible that it could already have been brought from Voromaa as a Catholic remnant. However, it is more plausible that it was acquired in Latgale. For Catholics the fragmentation of an important prayer may simply indicate that Lutsi did not have the status of a church language or, more generally, that of a "sacred language", which is also the reason why they began praying at home in other languages.

Oskar Kallas's notification of the fact that the version of the Lord's Prayer he recorded from the Lutsis (1894: 55) corresponds to the Lutheran tradition is entirely appropriate. This can, of course, be explained by the emigration of the Lutsis from Lutheran Vorromaa only in the 17th century (or at the beginning of the 18th century), but not necessarily. As Kallas himself observes, the entire population of Latgale, regardless of ethnicity, had been evangelical after the Reformation and until this territory came under Polish rule in 1660. Assuming that Lutsi settlement had existed earlier, the final doxology of the Lord's Prayer (...sest Sinu päralt on riik ja vägi ja au igavesti '... for thine is the kingdom, and the power, and the glory, for ever and ever'), i.e., the Lutheran version, may have been acquired in or around Ludza.

At this point it pays to draw attention to the fact that the Orthodox Church also uses a shorter version of the Lord's Prayer without the final doxology. Therefore, the Lutsi Lord's Prayer is least compatible with the view that they came from Setomaa. Kallas draws attention to the difference in Lutsi where on one hand there is ezä 'father', ezänd 'head of the household', but on the other hand there is Issand 'Lord'. That is truly interesting, but even more interesting is the fact that the same distinction applies to the Kraasna language (Kallas 1903: 65). Clearly this difference is related to the language of the church (scriptures). For South Estonian speakers, it was probably easier to accept the different meanings of esänd and Issand. It should be noted that already on the title page of the New Testament published in 1686, the form Issand is taken completely for granted, but at times, for example in Matthew 6: 1, 6, 8, 9, uses of Essa and Issa mix one with another. This inconsistency appears also in John 14: 8, 9 where the word Essand is used to address Jesus and Jesus speaks of his heavenly Essa. In fact, this difference also appears already in earlier South Estonian sources. Kristiina Ross speaks of expressions that arose and became ingrained during the Catholic 
period, in connection with difficult to explain places in the 17th century North and South Estonian pericopic books (Lohk \& Ross 2019: $100,101,104)$. This difference among the Lutsis is more suggestive of emigration from Vorromaa. Of course, more extensive migration to areas populated by the Lutsis already earlier should be considered. It is hard to believe that such a church language could have developed there independently of the church language of northern Estonia. The Kraasna Issand may come from contact with the Lutsis or could be explained by the Kraasna community also migrating from Vorromaa.

\section{Folk songs}

While historical accounts attempt to leave the impression that they are giving a direct and truthful account of the past, other types of folklore do not promise quick or easy answers. It is clear that something can be inferred about the past of a people who have such traditions only after careful analysis of many folklore texts.

Very little has been written about Lutsi folk songs - only a few remarks in discussions about different genres. For example, Herbert Tampere concluded, on one hand, that Lutsi calendar customs and the few documented calendar song styles correspond to those of southeastern Estonia, but on the other hand, they also show Seto-type features (Tampere 1960: 25, 29). The only exception is Elmar Päss's study of the Lutsi variants of the song type "Parmu matus" (The gadfly's funeral). The results of this work are not particularly influenced by the fact that, as an Orthodox follower of the Finnish school, Päss had compared reconstructed lines. He concluded that the Lutsi variants have a closer connection with those of Vorromaa and especially those found in Vastseliina and Räpina parishes, which border Setomaa (Päss 1927: 100-101). Päss likewise noted a close connection between the Lutsi variants and those of Setomaa. In fact, there is reason to believe that the Vorro-Seto distinction is not significant for that song and that Päss erred in omitting Setomaa from further study (Päss 1927: 101-102).

It is quite likely that following a new set of observations, the Lutsi "Parmu matus" variants would fit into the distribution group, which Arvo Krikmann identified in publications of South Estonian riddles as Group G3 (consisting mainly of Setomaa, its neighbouring parishes (Vastseliina, Räpina), and/or the language islands (Lutsi, Leivu, 
Kraasna)) or perhaps also Group G2 (a wider area of distribution in which Seto clearly dominates) (Krikmann 2000: 333-335).

The portion of Lutsi maarahvas containing language examples includes a total of 155 Lutsi songs and song fragments with different forms and features (a few cases, e.g., No. 148 and 150, may be short forms of runic songs), some of which are variants of the same song type. Oskar Kallas often chose not to write down the variants in their entirety (for example, No. 122 and 124 give only the lines differing from previous variants). According to Kallas, he did not write down again, that which he "juba sõna-sõnalt olivad" (already had word-for-word) (Kallas 1894: 78). In any case, it is certain that many of the important song groups and individual texts found in Kallas's book were documented at the last minute. Following established practice, Kallas primarily published "Laulud laulust" (Songs about singing). It contains only two texts with contemporary type names "Lauliku vaev" (A singer's anguish) and "Laulikule juua" (To drink for the singer). Both are songs with many variants known across all of Estonia.

\section{Laments and sorrow songs}

Let us now take a closer look at a genre, which for Finnic nations has a more direct or indirect connection with runic songs - namely, laments. Did the Lutsis know laments at the time when their heritage was recorded? In Oskar Kallas's publication, laments do not form a special section. These can be found in Section III as "Vaeselapse laulud, nutu-, murelaulud" (Orphan songs, crying, weeping songs) and there are also some wedding laments in Section VI - "Pulma laulud" (Wedding songs). Kallas uses the title "Vaeselapse laul" (Orphan's song) for the first four in Section III, of which at least three (No. 12, 13, 15) show considerable similarity to orphan songs from southeastern Estonia, though No. 14 is clearly translated from Latvian. The same surely can be said about Lutsi orphan songs as about those from Vorromaa: they are filled with unhidden sorrow and despair leaving the impression that they describe a recent loss. Simple repetition, exclamatory lines, and (rhetorical) questions are used as artistic techniques. If not a lament, then these songs are very close to laments. In Seto tradition, it is nearly impossible to say whether a text recorded in writing by dictation is a 
lament or a song (Salve 2000), thus it is not surprising that this is also the case for Lutsi. The noticeable isosyllabicity at the end of No. 12 in particular gives this impression. The same can be said about the last couple of lines of No. 13. However, these are just impressions. Nothing more certain can be said without knowing the situation in which they were performed or their melody. Here we recall that Oskar Kallas has nevertheless described Lutsi funerals, but unfortunately it is not possible to precisely understand his sentence in the funeral description: "Naised nutavad, karjuvad teel läbilõikava häl̈lega, niisama ka haual" (Women weep, wail with piercing voices on the way and also at the grave) (Kallas 1894: 51). Was that a Lutsi lament or just regular crying? It is quite plausible that Kallas was just not able to identify a phenomenon unfamiliar to him on the basis of a first auditory impression. If the wailing also contained distinguishable words, then it was still not enough for this researcher to have been able to put together a meaningful text in a distant South Estonian language.

No. 16 is most directly reminiscent of a Seto lament, due to its repeating refrain word koolokonno 'the dear deceased', but the next "sorrow songs" are again very difficult to place on the song-lament scale. Are they songs or laments in the tradition of Voromaa or Setomaa? No. 20 and 21 are slightly more likely to belong to Seto tradition where the song type "Kolm vaest" (Three Paupers) has received an epic development, but No. 25 is perhaps related more to the Vorromaa song repertoire.

A host of difficult to answer questions are also found in the most lament-like Lutsi text. This is "Sõjamehe lahkumine" (26) (The soldier's departure), so probably a conscript's lament. The first 15 lines of this text are farewells with a repetitive structure, the wording of which shows an improvisational style, despite the use of traditional word pairs (Maar'a maakõnõ 'dear land of Mary'; halas hainakõnõ 'dear green grass'). The next lines (16-43) are based on lines or formulas, which are known from the song types "Kasvatus asjata" (Raising in vain), "Tütar vette" (Daughter into the water), "Venna sõjalugu" (Brother's war story). The similarity of the beginning of the Lutsi text to the Latvian song for a bride leaving her father's home is very significant (Lautenbach 1896: 100). In summary, the heterogeneity of Lutsi farewell laments is reminiscent first of all not of Seto farewell laments (which also have a more unstable wording compared to other lament types), 
but fragments of chants documented elsewhere in Estonia (Tampere 1960: 205-206). Can the latter be considered the late remnants of an older lament tradition? In other words, the question is whether this is an example of a stagnant or forgotten and decaying cultural phenomenon. Seto lament culture represents a much higher level of development compared to these fragments. In Veera Pino's opinion, the inevitable subjectivity of the solution to the entire lament vs. song dilemma can be seen in the list of "clear or probable" Lutsi laments given in the introduction of Seto surnuitkud (Seto mourning laments), in which only a part coincides with those named here as possible laments (Pino \& Sarv 1981: 4).

As noted above, later collections, though much poorer and more monotonous than Kallas's collection, can still provide important additions in some cases. For example, Paulopriit Voolaine still met with Kallas's informants on a documentation trip in 1925 and wrote down variants of the same songs and possible laments, including a probable farewell lament performed by Jaan Herman (Kallas 1894, No. 26; cf. AES, MT 102, 22(1)), which provides a good opportunity for comparison. Also worthy of note is the mourning lament where the collector's explanatory sentence contains an interesting lament term.

"Tütar kuigõlõs (laulab nuttes venitavalt) ema haual" (A daughter wails (sings crying in a stretched manner) at her mother's grave):

\begin{tabular}{|c|c|}
\hline Maamakõnõ armakõnõ! & 'Dear mum, my dear one! \\
\hline $\begin{array}{l}\text { Lätsi Maar'a maa sisse, } \\
\text { verevä liivakõzõ sisse. }\end{array}$ & $\begin{array}{l}\text { You've passed into Mary's land, } \\
\text { into the red earth. }\end{array}$ \\
\hline Halla haanakõzõga & With green grass \\
\hline Kati'silma'kinni. & [they] covered your eyes.' \\
\hline
\end{tabular}

ERA II 33, 46(12) - P. Voolaine < Agata Jakimenko, age 80 (1930).

Two traditional forms present evidence for a Finnic source: the alliterative word pairs Maarja maa and hal'as hain, which appear in a number of story types. Correspondence to Seto and also lament traditions is shown by the word pair maamakõnõ armakõnõ 'dear mum, my dear one', which in Seto laments is a usual form of address used for a mother.

Among the Finnic peoples with lament traditions, the word kuigõloma 'to wail, lament' has no corresponding form. The exception, however, are the Leivus who know this word, but the extent to which its 
meaning overlapped with its meaning in Lutsi is not quite clear. What did the informant mean with the following words: ku ma zes ikki, zes ma ende ikki un ikki. ku ma zes vauglezi un kuiglezi, zes ma ende vauglezi un kuiglezi 'when I cried then again, then I just cried and cried. when I just wailed and lamented, then I just wailed and lamented' (Niilus 1937: 26, p. 48). As well as expressing the poetic-musical whole, the possibility must be considered that these may be asemantic cries and shouts of despair. The latter is also made more probable by the following sentence, according to which peni ka vauglezi un kuiglezi 'the dog also howled and whined'.

Unfortunately, Voolaine has not always included such informant explanations and we once again encounter the difficulty of distinguishing laments and songs. Help can again be sought from address forms (Tütrekene, mu armakõnõ 'daughter, my dear one' - AES MT 22, 2), also the interjection $e e$ (ibid.) may provide a hint - it could indicate a moan, sob, or other sounds related to crying.

Another obvious mourning lament (Mets et al. 2014: 270-271) repeats the address line (A mu tütrekene, mu kallikõno 'Oh my daughter, my precious one' or its variants), likewise several lines begin with $a$, which much like the aforementioned ee, was probably necessary for the lamenters as a way to take a breath, while simultaneously helping to structure the text. This rather long text can safely be considered a lament, but its origin is uncertain. It is quite distant from the Seto lament tradition as well as from the Vorromaa lament-like orphan songs and also from old Lutsi folk songs. We do not encounter traditional lines in this, let alone line pairs or groups, not even consistent word pairs, except perhaps käekeze kergekeze 'dear light hands' and vahadzõ hiuzõkõzõ 'dear yellow hair'. We recall that such word pairs are used not only in folk songs but also in short forms and folk prayers, for example kuri kotus, valge valuza päävä pääle 'an evil place, on[to] the white light [of the] sun' (Kallas 1894: 56). Perhaps Lutsi laments show a mixture of early traditions with those of neighbouring nations? It is to be expected that in a community with declining mother tongue use borrowed songs would appear including in the category of "sorrow songs and laments". In addition to the aforementioned Latvian loan No. 14, the quatrain No. 24 can without hesitation also be considered a loan. The matter is more complicated with text No. 18. Its structure also seems unusual (with the exception of the first line, of course, which is a line familiar 
from runic songs). A clear parallel with Veps tradition forces us to abandon the assumption that this could be a Latvian loan. A song has been documented from the Veps, which contains the same keywords: cuckoo, branches (= trees, in Lutsi), family members who are found to be missing:

$\begin{array}{ll}\text { Tuli kägoi vastha } & \text { 'A cuckoo came to meet } \\ \text { Kaik oksaized lugi } & \text { [It] counted all the small branches } \\ \text { Ühted oksast ei olend } & \text { One branch was missing } \\ \text { Kedak sinaiz ei olend } & \text { [there] was no one like you }\end{array}$

Ei ole sötjad tatoihuttain. the one who fed me, [my] dear dad, is no more.'

(Setälä \& Kala 1935: 377/9 (183))

The Veps song consists of several repeated episodes, each of which announces the absence of a family member. It cannot be ruled out that originally the Lutsi song was also long and multi-episodic, because this type of repetitive structure was still known - even favoured - by them ("Joodiku kojukutse" (Calling the drunkard to come home) or "Ema üle kõige" (Mother above all), Kallas 1894, No. 116-118). Since it is not possible for the Lutsi and Veps songs to originate from the same ancient source and its likewise impossible for the Vepsians to have borrowed a Latvian song, it remains to search for a common source in Russian (Slavic) tradition.

\section{Wedding songs}

Several possible wedding laments (No. 65, 66, 81, 91, 92, 93) are clearly visible in Section VI ("Pulma laulud" (Wedding songs)). Apparently, Oskar Kallas considered them to be "leinavateks" (for mourning) in his notes concerning wedding song refrains (see Kallas 1894: 97). Most of them contain address forms (Velekene armakene 'dear brother, beloved one'), which are also found in Seto bridal laments. Three of the mentioned "lament candidates" are related to "pääköitmine" (head binding), i.e., the practice of placing the headscarf worn by a married woman onto the bride's head; however, the address lines facilitating identification of the genre do not appear in two of these. When comparing texts No. 92 and 93 with text No. 94, the same "head 
binding" appears, but the difference between the first two and the last one becomes immediately apparent. In the first two, there is a complaining and plaintive tone, the lines, especially those of the fragmented No. 93, vary considerably in syllable number. A completely different tone prevails in song No. 94, which is a mutual reproaching song characteristic of weddings. However, a hint of the bride's ritual weeping can be detected in it (Tedre 2000).

Of course, questions are raised by the fact that, at Seto weddings, lamenting occurred only during the first half of the wedding held in the bride's home, while the "pääköitmine" (head binding) took place in the groom's home either immediately upon arrival or at the end of the celebration (Kallas 1894: 68). Perhaps the solution is that, according to Kallas's description, the Lutsis combined two rituals: the brushing of the bride's hair - which other Finnic nations, for example the Votians and Vepsians, did on the eve of the wedding after going to the sauna and the putting on of the wife's headscarf, which was done only at the groom's home. The Latvians, including in Latgale and even in the Ludza region, had a custom of calling participants to the head brushing with a song, which took place before the head scarf was placed on the wife's head (Vītoliņš 1968: 1164, 1165: 423).

In addition to the observations above, there are a couple of lamentlike songs, which Kallas classifies as "minija laulud" (daughter-in-law songs) (No. 95, 97). The dramatic contrasting of a daughter-in-law's and unmarried young woman's periods of life is also very characteristic of wedding laments. Especially the beginning of No. 95 and starting with the second third of No. 97, one can see lament-like address lines and a noticeable lament-like feeling.

As we have already seen, a portion of wedding songs can also be laments, but likewise there are also songs which have no connection with wedding customs. They deal with relationships between young people (No. 63) or are fragments. In Lutsi wedding songs, two different historical layers stand out immediately, which can even be mixed within a single text. On one hand, old-fashioned, often pan-Finnic, wedding songs are well-represented, as for example "Puutus puusatu ette" (Came upon a hipless bride) and "Oota, kuni kasvan kaasikuks" (Wait until I grow up to be a wedding singer) (Kallas 1894, No. 61, 62). All of the so-called "kaasikute laulud" (wedding singer songs) must be considered old-fashioned. These include a series of praises sung by the 
groom's wedding singers for themselves and the groom (No. 71 et seq.) or mocking songs by the bride's singers to the groom's singers (No. 85).

Similar songs are also known among the Setos, the Leivus, in the Kraasna community, in Võromaa, Tartumaa, and (Ida-)Virumaa as well as by the Votians. With the exception of the Votians and residents of Virumaa, these were sung with various modifications of the refrain kaske-kanke.

As the distribution already shows, the wedding singer songs probably represent a very old tradition (Salve \& Rüütel 1989: 30-31). The kaskekanke refrain has been a kind of logo or signifier of wedding songs for South Estonian-speaking groups, so that for Russians and Latvians in Latgale it came to mind immediately when Oskar Kallas said he was collecting Estonian songs (Kallas 1894: 67). For the Leivus, the refrain appears to have been an axis around which material of different origins was added. Latvian wedding songs did not have refrains (see Vìtoliņ̌ 1968) and in general no system of refrains developed in Latvian work or ritual songs comparable to that found in southern Estonia, although Tampere $(1956,1956 a)$ seemed to see some commonalities in them. As far as Setomaa is concerned, it is thought that the tradition of refrains was lost in various singing styles in its southern part due to foreign influence (Sarv 1999: 298-307). But was foreign influence weaker on the Leivus? Probably not. Therefore, the difference must be noted in each case individually.

It is almost impossible to distinguish between older Seto and Võro wedding songs due to their great similarity. Looking back, it is not possible to answer questions about the earlier performance style, single- or many-part singing, etc. If many-part singing was known, was it similar to that of the Setos or that of (western) Vorromaa? At first glance, the address word tätäkene 'dear daddy' may seem to point towards the Setos; however, this word also appears in certain contexts in the colloquial speech of Võromaa.

A slight hint pointing in the direction of Setomaa is the fact that the wedding song "Velle vihtlemine" (Brother's whisking [in the sauna]), which is known by many Finnic nations and tribes (Kallas 1894, No. 72, Rüütel 1970), includes the same horse praise added to the end of a variant performed in 1925. The lines Püzüi no putsai puusa pääl,/ Linaseeme lehe pääl 'a bird feather does not stay on the hip, linseed 
[does not stay] on the mane' (AES MT 102, 21 (3)) are characteristic specifically of the Seto repertoire.

It is noteworthy, however, that Latvian loans have found their way into even a song style as conservative as wedding songs. Oskar Kallas includes notes such as "Läti keelest lauliku "ümberüteldud" ("Rephrased" by the singer from Latvian), apparently based on the singers' own words. Thus, on one hand, clear Latvian influences (No. 75) have been left unmarked, while on the other hand, among those marked as loans at least a part are runic-song-like lines (for example, lines $14-15$ in song No. 98 , most of which is translated very fluently from Latvian).

Sometimes we also find lines or line groups in Lutsi songs, which are not Latvian loans, but are also unknown in the Estonian tradition. A more reliable identification of these apparently locally sourced song components and perhaps even songs will only be possible if all runic song material is digitised and is added to the database (www.folklore. ee/regilaul/andmebaas). Already in its current form, the runic song database was a great help in writing this article.

The local name for the groomsman - põksaja - reached the wedding songs. In a mocking song about the groom's wedding party (Kallas 1894 , No. 85, 86, three later transcriptions by Voolaine in different collections from one singer) several parallel lines describe who is sitting on the back of whom (or what). In this song, sits põksaja põdra sälähn 'the groomsman on the back of an elk', but the bride, for example, is sitting alternatively on mõhe 'a bread trough' or mõoga 'a sword', etc. The striving for alliteration is very strong.

\section{Calendar songs}

Following Oskar Kallas's classification of Lutsi songs, we reach holiday songs or, according to their modern name, calendar songs. These include two Shrove Tuesday (Estonian: vastlapäev) songs, one Palm Sunday (South Estonian: urbepäev) song, and eight "swinging songs" (Estonian: kiigelaul). The case of the Shrove Tuesday songs is clear. It is clear that these are connected with Vorromaa tradition both in terms of content and refrains, for which there is no evidence in Setomaa Maaselitsa (Shrovetide) songs. The first of these Shrove Tuesday songs (No. 49) contains mourning motifs indicating the approaching fast, 
which are typical of Seto Maaselitsa songs, but which also fit well into the Catholic context of Latgale.

Quite a few questions are raised, however, by the only Palm Sunday song. Perhaps Ülo Tedre's Seto hypothesis was also partially inspired by Oskar Kallas's parenthetical note ${ }^{1}$ after Urge päiva /urbepäeva/ laul (Palm Sunday song) ("I heard the same song in Setomaa; "tsõtsõ" is an exclamation called out in rhythm with the movement of a swing." see 1894: 94). It is only surprising that Kallas noticed this similarity with a Seto song, but nevertheless wrote the Lutsi song refrain word as tsõdze. In light of the Seto traditional tsõó-tsõõ refrain, it is clear that Kallas made a mistake. Perhaps he confused an asemantic refrain word with a similar kinship term (i.e., aunt)?

A refrain word occurring at the beginning of a line is found in several types of Seto songs, also in variants of the Palm Sunday song. However, another style exists: the refrain word occurs at the end of a half-line or line. This latter style is also known in the work and ritual songs of Võromaa (and more broadly in southern Estonia and in South Estonianinfluenced central Estonia) (see, e.g., Vissel 1988: 173, 177, 189). However, no real Palm Sunday songs are known from Võromaa (or from southern Tartumaa and Mulgimaa), therefore, at least in the 19th-20th centuries these were only part of the tradition of the Setos and Lutsis.

Swing songs are well-represented with eight texts in Oskar Kallas's book. Literally only two of the swing songs are associated with Easter (No. 52, 53), Kallas probably titled the third (No. 54) "Lihavõtte hällü laul" (Easter swing song) according to the singer's own description, the holiday is also named in Song No. 55. In all of southern Estonia, including Setomaa, but also in Latvia, swinging and swing songs are associated with Easter. Lutsi swing song refrains correspond to the refrains known in southeastern Estonia (also in Setomaa), which vary though in their sound structure: in Lutsi, for example, Häde eiu kuku; Häde eia kako. And, incidentally, Kallas recorded the same refrains with small variations in Kraasna. Very few swing song melodies have been recorded from the Latvians, and most of them also come only from Latgale (Vìtoliņš 1973: 49). In this context it should be noted that the known Latvian swing songs do not have refrains.

1 "Sama laulu kuulsin Setu maal; "tsõtsõ" on hüüdsõna, hüütakse ühes taktis laudkiige liikumisega." 
Among the calendar songs, Oskar Kallas also included one, which is described as a "talze pühi laul" (Christmas song). This is a game song, which represents the newest revisions of the "Väravamäng" (Gate game). Since Christmas time was the most important time for playing song games, then it is also understandable to name the corresponding song after Christmas.

But where are the Lutsi Martinmas (Estonian: mardipäev) and St. Catherine's Day (Estonian: kadripäev) songs? The complete disappearance of these over a couple of centuries is difficult to explain only with the surrounding population not being familiar with Martinmas or St. Catherine's Day mummers. Marking the feast days of saints in this way would also not have been contrary to Catholic principles. The fact that the Latgalians and Slavs practiced mumming on Christmas should not have ruled out the Lutsis mumming on Martinmas or St. Catherine's Day. By comparison, the Livonians continued to go mumming on Martinmas even though their Latvian neighbours were unfamiliar with this custom, but still learned from them to go mumming on Shrove Tuesday with the corresponding songs (Salve 1984).

It is clear that already by the 17 th century, not to mention the beginning of the 18th century, Martinmas traditions together with corresponding songs had to have developed in Estonia long before. Otherwise, it is simply not possible to explain their all-around correspondence - in words and melodies - to runic songs. The oldness of Martinmas and St. Catherine's Day songs is also indicated by the developed unique regional characteristics. This question is very intriguing. The matter is also not made clearer by several Leivu Martinmas songs or fragments, which were recorded by Valter Niilus (AES 154: 20), since one of these is clearly a translation and only one line has been recorded from the other two, thus nothing can be concluded based on them.

Incidentally, Oskar Kallas only recorded a few fragments a couple lines in length in Kraasna, in which, at least, Märt is mentioned (Kallas 1903: 107, No. 2). Based on this it is not at all clear whether this is a mocking of someone because of his name, a fragment from a description of the difficult Martinmas journey, or something else altogether. 


\section{Joking and mocking songs}

Oskar Kallas placed very different kinds of songs in the section "Nalja laulud, jorutused, pilkamise laulud" (Joking songs, droning, mocking songs). Here is the hyperbolically boastful "Küll mina olin mees" (Sure, I was a man) (the type name used today is "Noorena võtsin kirbu kinni" (I caught a flea when I was young), No. 30). This was also widely known in Estonia. By contrast, "Poisse pilgatakse" (The boys are mocked; No. 46) and "Peretütart pilgatakse" (The farmer's daughter is mocked; No. 47) have no direct equivalent. The first one still contains allusions to runic songs, in the second one we encounter a clearly intentional example of alliteration, but its metre is quite variable and leans more towards the characteristic six-syllable structure of children's readings. The opening lines of "Naisi pilgatakse" (Women are mocked; No. 48) are unclear, but this is clearly due to forgetting, because the last three lines strongly refer to the runic song type "Teomehe tillike" (The corvée peasant's willy), which is widely known in Estonia.

In this section, we also find humorous children's songs or readings about animals or birds ("Parmu matus" (The gadfly's funeral), "Tsiri, tsiri tsirgukene" (Chirp little bird), "Kits, mits habõnelle" (Goat with a beard), etc.) as well as the cumulative "Läätsä lää ei kotti" (Lentils do not go in a bag), which stands between a fairy tale and song.

Two different dance songs (No. 31, 32) are identified by the singer as "old Swedish songs", which excludes the possibility of learning and/ or creating them on site. But while these songs give a close and familiar impression, it is not so simple. It seems possible that these songs, while using runic song techniques and containing specific traditional elements, for example, word pairs, only received their current form among the Lutsis. Dance song No. 32, which was documented later also from the Lutsis, is clearly based on songs such as the "Pudrukeetmine" (Porridge cooking), which uses a chain of parallelisms based on first names, and "Löö pilli" (Play a tune), which speaks about playing a musical instrument, but some alliterative word pairs, such as pikk Piitre 'tall Piitre', are also traditional. In the case of dance song No. 31, it is not possible to refer to a specific song. It seems to have been constructed from smaller parts, for example, lines, half-lines, word pairs, beginning with tantsivast tammest (about a dancing oak tree) in the first line. 
Very intriguing are the two or three variants of "Minä lätsi mõtsa" (I went into the forest) (No. 43 and 44, lines which differ are noted next to the latter song), which Oskar Kallas could have easily placed with the narrative songs. The beginning of the song makes one think of a borrowing, but then come alliterative lines and traditional word pairs. Hunting and catching an animal (in this case, a goat), getting and hiding fat, the unwanted spread of a secret are reminiscent of runic song content motifs. In the end, the protagonist speaks about punishing himself with the lines

Sai suure suningu, Rase raha massangu,
'[He] got a big judgment, a difficult money payment,'

for which no correspondences could be found, though the word pair rahaline raske (difficult to pay) exists in the tradition as both lines might. Of interest are the derivations of the verbs sundma 'to force' and masma 'to pay', the first of which is still used in its old sense (to judge).

Finally, there is another song in the same section referred to by the singer as a "talsepühi laul" (Christmas song) ("Mina olin ka" (I was too; No. 42), which is a unique earlier version of the widely known game song "Metsa läksin ma ja metsa läksid sa" (I went to the forest and you went to the forest). This, like the aforementioned variant of "Väravamäng", has, in turn, given a basis for dating the age of Estonian songs associated with migration, still based on the theory that the Lutsis are descendants of 17th century immigrants (Rüütel 1971: 13-14; 31-33).

However, as already noted above, one can also imagine one or another song arriving in the Ludza area even with fewer or later immigrants. In addition, the uniqueness of No. 42 makes one reexamine possible borrowing relationships.

\section{Narrative songs}

Next, we take a closer look at narrative songs, which, in Ülo Tedre's opinion, provide a basis for a Seto origin for the Lutsis. First of all, it must be said that, according to Oskar Kallas's classification (which Tedre appears to have fully accepted), Section VII entitled "Jutustavad laulud" (Narrative songs) also includes several songs, which, based on modern understanding, should not be here. Songs about birds and 
animals, which belong to the repertoire performed to children, are included in this category and similar ones have also been included with joking and mocking songs. Often, they have a narrative element.

It is worth nothing that "Kits ja hunt" (The goat and the wolf; No. 123, $124,126)$ - apparently popular among the Lutsis - also has a parallel story in the Caucasus (Anderson 1927). There are also translated loans among the narrative songs (No. 133, 134, probably also 114). Kallas did not mark any of these as translations. A good example of a song whose origin Kallas probably did not ask about (or the singer claimed to have heard it from someone in Estonian) is No. 134 ("Kazus roosakene tee veerehn" 'A little rose grows on the roadside'). This is a song where suitors are compared, which is unknown in this form in Estonia, including among the Setos. The dislike of an old man and desire for a young one is expressed through other images. Since Latvians also have songs about the same subject, the Lutsi song is probably derived from them. The opening line already points in that direction.

Repetition songs are strongly represented among the more runic-like and genuine narrative songs: "Haned kadunud" (The geese are lost), "Ehted kadunud" (The jewellery is lost), "Hobune kadunud" (The horse is lost), but also "Joodiku kojukutse" (Calling the drunkard to come home) (Kallas 1894: "Ema üle kõige" (Mother above all) or "Vanemad üle kõige" (Parents above all)) - so nothing Seto-specific. Note that there are three to five variants for each of these song types. Among the Lutsis, there are no older narrative songs from Võromaa, but likewise from Setomaa, there are none of the interesting songs referred to by Jakob Hurt as "muinasusulised laulud" (songs of ancient beliefs, Hurt 1904). Seto "ristiusulised laulud" (Christian songs) are represented by "Jeesuse surm" (Jesus's death), which is the only documented Lutsi runic-style legend song and appears as two fragmentary versions (Kallas 1894, No. 131 and 132). Could "Jeesuse surm", which is known to us as definitely being of Seto origin, have also earlier been known in Vorromaa? The presence in Võromaa and southern Tartumaa of often fragmentary versions of individual archaic fairy tale and song types known in Setomaa at least allows for this possibility. The 17th century intangible culture of Vorromaa is not revealed particularly exhaustively in the folklore collections of the second half of the 19th century. However, it is very likely that "Jeesuse surm" as well as several other Seto elements entered the Lutsi song repertoire thanks to Seto migrants. 
A few narrative songs also stand out as they have no direct correspondences elsewhere in Estonia. For example, "Sulane künnil" (Farmhand ploughing) (Kallas 1894, No. 111-113), which includes corresponding lines from different songs, but as a whole, extended through motif repetition, is completely unique.

For many songs, I would not risk to state anything. For example, lines $2-5$ of No. 114 ("Kolm tütart" (Three daughters)) are typical opening lines of a Seto narrative song. Moving further into the forest as she picks berries, a girl reaches the seashore, she chats with a fisherman and at the end of the song there are probably orphan song motifs, but there is nothing about it at all reminiscent of a runic song. Most likely this is a translation of a Latvian song, to which some of the motifs also refer.

Songs, which at least in 19th-20th century Estonian folk tradition have been categorised as children's songs, can be found in quite a few sections in addition to II, which is called "Laste laulud" (Children's songs). Along with several traditional South Estonian lullabies and playing songs, it also includes a fairy tale song related to the Seto repertoire (No. 6) and an endless tale about the rejection of a request to narrate the story (No. 9 and 10). Grouped with the children's songs, the opening line of No. 11 Kur'g, kär'g, kus sa olid? 'Crane, [black] woodpecker, where are you?' seems very genuine, but may be borrowed in its entirety. Incidentally, texts that are essentially children's songs can be found also in other sections, for example "Mitmesugused riismed" (Various remains).

Folk songs can hardly be classified in such a way where there would not be a few, which do not seem to fit anywhere. Oskar Kallas has called this section (VIII) "Mitmesugused riismed" (Various remains). It comes as some surprise that many of them (No. 135, 136, 137, also No. 143) are clearly herding songs, the first of which has the lere refrain. In southern Tartumaa and especially in Võromaa, there are herding songs with similar refrains (leli, leele, leelo), but precisely this one does not appear to be found in the Estonian material. Herding songs in Setomaa are known to have no refrains. These herding songs are the only Lutsi work songs, which have reached us today. Again, this cannot be seen as completely accidental. Functional work songs do not make up a proportion of Latvian songs comparable to that of Estonian songs; and herding songs are those that specifically are most numerous (Vìtoliņš 
1958). However, there is a harvest song in the much smaller collection of songs recorded in Kraasna, though with a secondary kaske-kanke refrain taken from wedding songs (Kallas 1903: 114).

Some of the other texts found in this section include short forms (No. 148, 150) or song fragments a couple lines in length whose song type could not be determined. It is also difficult to say anything about the quatrain No. 141, which seems to use alliteration, though its line pairs are not related to each other and also do not have any correspondences in the Estonian repertoire. More than in other sections, there appear to be Latvian borrowings here (in addition to those noted by Kallas, probably also No. 141, 142, 144).

\section{Narrated songs}

There has already been reason in many cases to mention songs with an unclear form. In exceptional cases, there are texts, which can in no way be considered songs, though they are based on song plots. Let us take a look at a couple of these from August Sang's linguistically accurate documentation in the Academic Mother Tongue Society (Akadeemiline Emakeele Selts) collection. The first (see Mets et al. 2014: 137-138) is the story of a woman's murderer. The Lutsi text is reminiscent of the Seto (or, more broadly, the southeastern Estonian) "Naisetapja" (The woman's killer), but the correspondence is not very precise. It is missing the important final episode of "Naisetapja" with the criminal's repentance and punishment. On the other hand, the Lutsi story ends with the children being killed by wild animals that are summoned by their dead mother. The killer is the husband himself, so there is no place for the episode of visiting a tavern where the murderer is found. This rather concise Lutsi text is at its core about the children's search for their mother and the father's untruthful answers. The consistent wording used to address the father seems like a formula: Ezä, sa mi däädä, kon mi maama? 'Father, you [are] our daddy, where [is] our mummy?' In this text, the word pairs soo veer - tee veer 'swampside, roadside' as well as vahtse vihaga vihtumine 'thrashing with a new whisk' have a Finnic background. There is probably no direct connection between this Lutsi story and "Naisetapja". Instead, it is likely a retelling of a ballad from another nation's repertoire in Lutsi. 
Another text recorded by Sang (Mets et al. 2014: 134) also prompts a comparison with runic songs, namely "Venna sõjalugu" (Brother's war story). As also in the previous case, there are significant differences between this text and the usual form of this very popular song in Estonia, including in Setomaa. Missing parts include the opening motifs with news about the war and discussions of who must go to war, but also the brother's return in the end, other family members not recognising him, but his sister recognising him, and a dialogue between the siblings. The Lutsi text begins with this introductory sentence: Sääd jo imä poiga sõtta. 'Mother is already preparing her son for war.' Next, the mother as well as the three sisters and wife ask about the time of his possible return home. From the metaphorical answer given to the wife, it is clear that there is no hope of him returning home. The essentially impossible conditions for returning home are also featured in some of the variants in Estonia, but they are completely different.

Also in the case of this Lutsi text, a prose retelling of a song of Estonian origin can be ruled out, because their plots are too different. "Venna sõjalugu" is widely known among Baltic and Slavic nations, likewise there are parallel ballads about a woman's killer. Ballads have spread from nation to nation in such a way that they were taken from a foreign language and formulated into a song sung in one's own language. It may be that at some earlier point when Lutsi was still more vital, these stories told to Sang also would have taken the form of a song.

Compared to the aforementioned texts, the third one recorded by Paulopriit Voolaine is relatively unproblematic: Poeg käskis ema vett tuua kirvest ihuda, minija käskis tuua vett leiba kasta. Jummal' ei tahtnud seda ja muntis poja "sokast soo viirde", minija "tedrest tee veerde" "The son ordered [his] mother to bring water for sharpening an axe, the daughter-in-law ordered [her] to bring water for making bread. God did not allow it and turned the son into a duck on the edge of the swamp, [and] the daughter-in-law into a black grouse on the edge of the road' ERA II 33, 24(1) < Lutsi, Pilda parish - P.Voolaine $<$ Meikul Jarošenko (1930).

Probably the narrator fumbled about so much when telling these fragments that the collector did not try to record them verbatim, as he did for speech in verse texts. However, two (incomplete) lines leave no doubt that the informant has heard (or even known) the narrative song 
"Tütred lindudeks" (The daughters become birds). Kallas (1894: 112) gives a 4-line fragment of the same song under the title "Kolm tütart" (Three daughters). The fragment corresponds to the normal form of the song and could easily be placed into the body of the entire song. By 1930, however, the relationship among events had already become confused: the innocent girls do not become birds at the son's urging, but instead [of the girls] the son and daughter-in-law do. Additionally, the metamorphosis is presented as God's punishment, as is often the case in creation stories. If the performer had not remembered the core words in two lines, which made it possible to clearly identify them, this would have resulted in one racking one's brain in vain, as is often the case for texts from fading traditions.

\section{Comparisons with Kraasna and Leivu}

Although Lutsi songs have been compared with those of the other South Estonian language islands a number of times, it is worth it to stop by Leivu and Kraasna for a moment. Again, our knowledge of the Kraasna community is largely based on the work of Oskar Kallas. After him, only Heikki Ojansuu still managed to record language examples, including folklore texts. Kallas also published his invaluable material as a book (Kallas 1903), which presents the view that the Kraasna community is of Seto origin. As with the Lutsis, he has also relied here on oral historical tradition as well as linguistic and ethnographic observations.

The assertion that the Kraasna language island inhabitants were of Seto origin should, however, still be tested in several ways. Oskar Kallas was a competent philologist, but it should be noted that if we accept the possibility that migration occurred as early as the second half of the 16th century, then certainly a number of archaic features which are now characteristic only of Seto were historically known across a wider area of southern Estonia. For example, there are words found in the Vastne Testament (New Testament; 1686), which uses the Tartu dialect, that are known only in dialect collections from Setomaa (Peebo 1989). Russian influence may have appeared independently of each other in Seto and Kraasna. As for toponymy, to which Oskar Kallas himself assigned importance, it can be noted that Naha village in Kraasna is the namesake of a village in Räpina parish in Vorromaa. His 
remarks about folk costumes do not leave a very convincing impression (Kallas 1903: 27-29), because while confirming the Seto origins of Kraasna clothing, Kallas also acknowledges that considerable changes took place in Kraasna folk costumes during the 19th century. Certainly, he had considerable expertise regarding folk costumes thanks to his earlier experience in collecting (Õunapuu 1998: 77-82).

The absence of laments here is a real quandary when claiming a Seto origin for the Kraasna community. The absence of laments in Kraasna is further emphasised by the fact that later this community was also in contact with its supposed original home. Kallas also mentions his informants' reports about brides who came from Setomaa (Kallas 1903: 46). Since laments have always been a women's tradition, then it could also be assumed that arrival of fresh blood preserved the lament culture at least to some extent. Does this indicate that the presently known Seto laments developed as late as the 17th-18th centuries or that the Kraasna community originated from somewhere other than the Setos?

Kallas noted that wedding songs in their language remained in use in Kraasna for a relatively long time, but he also managed to record work and calendar songs. The surviving songs were - as was also often the case for the Lutsis - relatively heterosyllabic. Perhaps some of them had their own characteristic performance style already from the beginning, which Kallas describes as: "laulva häälega, venitades - mitte jutustades - öeldi" (with a singing voice, said by stretching - not telling) (Kallas 1903: 103). This could indicate a lament, but likewise a charm or incantation. An incantation-like quality is also strongly evident in, for example, No. 14, which is a harvest song.

In the case of the third South Estonian language island - the Leivus or Gauja Estonians - the picture regarding their self-designation and historical origins has also been colourful and contradictory. Though they have their own stories describing their "Swedish" origins, it is fairly universally held that they are indigenous. The Leivu folk songs were collected a generation after O. Kallas's Lutsi expedition, beginning with Paulopriit Voolaine's first trip to the Leivus in 1926 and continuing with Valter Niilus's fruitful expeditions in 1935 and 1937. Therefore, it would be more useful to compare what has been collected with the Lutsi materials Voolaine and Sang recorded.

Valter Niilus published the Leivu folk songs he collected, and he correctly points out that the first of these is a translation of a Latvian 
orphan song "Maziṇš biju, neredzēju" 'I was little, I didn't see' (Niilus 1935: 380, 381). In fact, this Latvian-origin song with the opening verse in Estonian "Väike olli, es ma näe" 'I was little, I didn't see' became very popular in southern Estonia no later than the end of the 19th century, where it was grouped with runic-song-like orphan songs and remained in circulation for a long time. The Leivu version is a completely independent translation, which is considerably rougher and more uneven than those sung in Estonia. By the way, the Lutsis also knew this Latvian-origin song.

Three major groups can be distinguished for Leivu songs, namely, chain song readings typical of the children's repertoire, wedding songs, and translations of Latvian songs. The latter two groups partially overlap, for example, wedding songs obviously borrowed from Latvian but sung with the kaske-kanke refrain. There is little from everything else and often fragmented song texts are difficult to classify in terms of their genre. The Leivu song repertoire may have been richer during earlier generations, but it certainly had been under strong Latvian influence for a longer time. In addition to the translated songs, songs were also sung in Latvian. The last knowers of Leivu songs may have even been the most prominent Latvian folk singers in the area (Niilus 1935: 378).

The Leivus' situation was different from that of the Kraasna community, among whom Kallas did not observe a significant circulation of songs in Russian. (Kallas 1903: 104). A comparison of the three language islands shows that there is much more translated material in the Lutsi material than Kallas stated in his publication, that there was quite a lot in the Leivu material, but that in the Kraasna material translated loans apparently are rare. Kallas remarked that only one song (Kallas 1903: 112, No. 8) had been translated from Russian. Indeed, there is no doubt about any other songs that they could be translations. There is no reason to think that Kallas would have avoided recording translated loans in Kraasna, if he had not avoided doing so with the Lutsis. Of course, the total amount of Lutsi material is much greater than that from Kraasna, but there are also considerably more loans. It can be assumed that in Kraasna, where at the beginning of the 20th century there were few native speakers left, singing was already mostly in Russian and so there was no longer any need for translating. However, Kallas's remark should be taken seriously, as accordingly Estonian songs were not replaced by Russian ones in Kraasna, but instead disappeared altogether. 
Here, an important difference must be noted between the Lutsi and Leivu relationship with the Latvian repertoire and the Kraasna relationship with the Russian one. It was clearly easier to integrate Latvian and Lutsi-Leivu-Estonian songs. We can come across portions with two different origins within one text and in some cases, it is almost impossible to say what we are dealing with: there is no known corresponding runic song, but there is intentional alliteration and parallelism. An example of this is this wedding song (No. 89):

Lää ma tarrõ kaema, Kas istus mu t'ät'ä lava odzan, Kas kiird mu imä kezet tarre,

Kas istus mu hõim hõ'ilan?

Tere laud lõhmusine,

Tere kanni kadjatse,

Tere pingi' pedäjätse'!

Ei istu mu ezä lava odzan,

Ei kiird imä kezet tare,
'I'm going inside to see,

does my dad sit at the head of the table, does my mum turn [around] in the middle of the room, does my family sit in a row?

Hello, lime-tree table, Hello, juniper mugs, Hello, pine-tree benches! My father is not sitting at the head of the table, my mother is not turning in the middle of the room, my family is not sitting in a row.'

Of course, there are direct correspondences to the first line Lä̈ $m a$ tarre kaema 'I'm going inside to see' - the same occurs as the usual greeting lines 5-7 in wedding songs. The questioning lines $2-4$ are repeated in the negative in $8-10$. In this example, there is actually no component of foreign origin, but, of course, among Lutsi songs there are also ones with very little connection to runic songs, but which visibly have a four-line structure. An example of this is No. 98, which the singer themselves acknowledged as a translation, but the last two lines are traditional runic song lines. Such examples are especially common in the Lutsi repertoire, while in the Leivu repertoire we encounter translations, which seem more literal, for example: 
Vahn jeza, l'ikatai, taht noort naist kuossi.

Lööge tõõnõ d'alg ka katski,

Saa veel nuorõba.
'[My] old dad has a limp, [he] wants to marry a young woman. Let's break [his] other leg, [he] will get an even younger [wife].'

(AES, MT 203, $30<$ Ilzene parish - V. Niilus < Anet Kalej (1937))

Among newer songs in (southern) Estonia, there are quite a few Latvian loans, which have already been noted in runic songs. The most striking examples of these are songs with the liigo refrain and also other Latvian-origin Midsummer songs found in parishes along the border with Latvia. More generally, it is incorrect to speak simply of Latvian influence or loans, but rather about similar characteristics, until more extensive research can be done to determine whether one or the other is the result of mutual developments or something else. There are also common old strata in Estonian and Latvian folk music. Ingrid Rüütel has found that up to $75 \%$ of Latvian wedding song tunes have Estonian parallels and likewise $45 \%$ of Estonian wedding song tunes have Latvian parallels (Rüütel 2001).

A comparison of Kraasna and Leivu riddles can be significant from the perspective of accepting foreign influence. In Kraasna riddles there is little material of Russian origin. Primarily they are quite South Estonian in character and strongly linked to language, for example through alliteration and rhythm. In Leivu riddles we do not find an equivalent expression of euphony. By contrast, we encounter Latvian-origin clichés and most of the riddles also have direct Latvian correspondences. In some cases, a Leivu riddle will occur only once in our story corpus. (Salve 2015: 285-309) In Lutsi riddles, which are much more extensively recorded, the situation is intermediate. Own and borrowed are equally common. It should be noted that in addition to Latvian loans, there is also a small amount of obvious Russian loans among the Lutsi riddles.

\section{A more distant comparison: The Tver Karelians}

Matti Kuusi considered the existence of runic-style proverbs in Finnic nations as an indicator showing whether they had ever had runic songs. He was able to observe that the Tver Karelians (as well as the 
inhabitants of southwestern Finland) had preserved runic-style proverbs, even though the old songs were vanishing or had vanished in their territories. This type of proverb has not been recorded from the Vepsians, as these, like the songs of the same form, apparently also had not existed (Kuusi 1978: 47). However, (in Kuusi's words) "language and culture shocks" left a strong impression on Tver songs. Let us illustrate what was said with an example of the song type "Kuolon sanomat" (News of death), which was also known to the Lutsis:

$\begin{array}{ll}\begin{array}{ll}\text { Oi vaivaine Vasleizen', } \\ \text { kunne sie suorielet? }\end{array} & \text { 'O my poor dear Vasle, } \\ \begin{array}{ll}\text { Suorielen mina suohuzih, muahuzih, } \\ \text { where are you wandering? }\end{array} & \begin{array}{l}\text { I am wandering through bogs, } \\ \text { meadows, }\end{array} \\ \text { vavarnazista fattietemah, } & \text { to look for raspberries, } \\ \text { marjazih keriämäh. } & \text { to pick sweet berries. } \\ \text { Tuli sana jällesta: } & \text { [Then] a message reached [me], } \\ \text { tuattos kuolomassa! } & \text { father is dying! } \\ \text { Kuolov ka kuolgah, } & \text { [He] is passing away, } \\ \text { suan mie tuammost tuatua nägomah: } & \text { I'm going to see my [dying] dad: }\end{array}$

(Niemi 1927: 1131, s 655/656)

The Lutsi variant of the same song type (Kallas 1894, No. 116 et seq., "Ema üle kõige" (Mother above all)) includes familiar lines with "limping feet". Clearly, they can be accepted as "old songs" only based on a more reliable form of the text from the same parish. The original song folklore of both the Tver Karelians and Lutsis contains a remarkably large proportion of children's songs and readings, chain songs, laments or lament-type songs. Within a single song, the degree to which runic song norms are followed is often variable: lines often have a fluctuating number of syllables, use of alliteration and parallelism is inconsistent. Among surviving runic songs, there are no song types reflecting older beliefs, traditions, or circumstances. Also among Tver Karelian narrative songs, songs comparing relatives are strongly represented, for example, "Surmasõnumid" (News of death), "Venesse pürgiv neiu" (A girl seeking a boat), suitor comparisons, etc. Various forms of incantations, both more runic-song-like and more prose-like, have an important place. 


\section{Conclusions}

Based on all of the observations above, it can be said that the picture is relatively uneven and also contradictory. Lutsi intangible culture divides into different groups and individual works defined by tradition, form, and theme. Must we avoid trying to say anything about the history of an ethnic group based on its oral tradition? Certainly not, but at the same time we cannot overlook some features while highlighting others. When considering the many components relating to the history of Lutsi settlement, features which appear contradictory seem quite expected. But it should also be kept in mind that many of the features we find in Lutsi oral tradition not only characterise them, but also are typical of many cultures near and far that are in the process of being forgotten. Runic songs form a very complete system and as such are also very fragile. It is quite impossible and difficult to decide what the peak of the development curve had been in the past based only on its final form.

Still in the 1920s, Lutsi children learned readings whose first lines have direct correspondences in Setomaa, but which as a whole seem quite unique. The earlier Lutsi variant was recorded by Oskar Kallas (1894: 121, No. 147), the later variant is this:

$\begin{array}{ll}\text { Tirka mullõ, tiiziken'e, } & \text { 'Leap at me, kitty, } \\ \text { Karga'mullõ, kassikõnõ } & \text { Jump at me, pussycat! } \\ \text { Kassil valgó'kapudakõzõ', } & \text { The cat has white socks, } \\ \text { tiizil til'l'o rätikene. } & \text { the kitty [has] a tiny kerchief.' }\end{array}$

(ERA II 33, 24(1) - Ludza, Pilda parish, Tsäpsi village - P. Voolaine $<$ Oodik Jaroshenko, 9 a. (1930/31))

Oodik's generation could still remember similar readings in their old age, but no longer passed on these Lutsi traditions.

\section{References}

Anderson, Walter. 1927. Imelik paralleel. Album M. J. Eiseni 70. sünnipäevaks, 28-36. Tartu.

Annom, Inge, Risto Järv, Mairi Kaasik \& Kärri Toomeos-Orglaan (eds.). 2011. Pühakud ja vägimehed. Muinasjutte Lutsi maarahvalt ja nende naabritelt. Tartu: Eesti Kirjandusmuuseum. www.folklore.ee/muinasjutt/lutsi.

Annom, Inge, Risto Järv, Mairi Kaasik \& Kärri Toomeos-Orglaan (eds.). 2018. Vaese mehe onn. Muinasjutte Lutsimaalt. Tartu: EKM Teaduskirjastus. 
Godiņš, Guntars. 2015. Ludzas igauņu pasakas. Godiṇš, Guntars (trans1.). Rīga: Mansards.

Grünthal, Riho. 1997. Livvistä liiviin. Itämerensuomalaiset etnonyymit. Helsinki.

Hussar, Anne, Arvo Krikmann, Erna Normann, Vera Pino, Ingrid Sarv \& Rein Saukas (eds.). 1980-1988. Eesti vanasõnad I-IV. Tallinn: Eesti Raamat.

Kalkun, Andreas. 2001. Mõistus ja tunded. Protestantlik ja ortodoksne Anne Vabarna tekstides. In Mall Hiiemäe \& Kanni Labi (eds.), Klaasmäel (Pro Folkloristica VIII), 45-65. Tartu: Eesti Kirjandusmuuseum.

Kallas, Oskar. 1894. Lutsi maarahvas. Helsinki: Suomalaisen Kirjallisuuden Seuran Kirjapaino.

Kallas, Oskar. 1900. Kaheksakümmend Lutsi Maarahva muinasjuttu. Tartu: Schnakenburg'i trükikoda.

Kallas, Oskar. 1903. Kraasna maarahvas. Helsinki: Soome Kirjanduse Seltsi Trükikoda.

Kallas, Oskar. 2008. Risto Järv, Mairi Kaasik \& Kärri Toomeos-Orglaan (eds.). Lutsi muinasjutud. Kommenteeritud väljaanne. Tartu: Tartu Ülikool. https://www.folklore.ee/UTfolk1/mj/lutsi/.

Kallas, Oskar. 2015. Maajumala poig. Tartu: Ilmamaa.

Krikmann, Arvo \& Rein Saukas (eds.). 2001-2014. Eesti mõistatused I-III. Tallinn: Eesti Keele Sihtasutus, Tartu: EKM Teaduskirjastus.

Krikmann, Arvo. 2000. Tere teele, tere meele, tere egalõ talolõ. Valik lõunaeesti mõistatusi. Tartu: Eesti Kirjandusmuuseum.

Kuusi, Matti. 1978. Suomalaista, karjalaista vai savokarjalaista (Suomi 122:2). Helsinki.

Lautenbach, Jakov. 1896. Otšerki iz istorii litovsko-latyšskago narodnogo tvortšestva. Tšast' I. Jurjev.

Lohk, Ahti \& Kristiina Ross. 2019. Joachim Rossihniuse ja Heinrich Stahli perikoopide võrdlus. Emakeele Seltsi aastaraamat 64. 65-110. https://doi.org/10.3176/ ESA64.03.

Mets, Mari, Anu Haak, Triin Iva, Grethe Juhkason, Mervi Kalmus, Miina Norvik, Karl Pajusalu, Pire Teras, Tuuli Tuisk \& Lembit Vaba (eds.). 2014. Lõunaeesti keelesaarte tekstid (Eesti murded IX). Tallinn: Eesti Keele Instituut, Tartu Ülikool.

Niilus, Valter. 1935. Leivu rahvas. Eesti Kirjandus 29(8). 365-381.

Niilus, Valter. 1937. Valimik leivu murdetekste. (Akadeemilise Emakeele Seltsi Toimetised XXXI). Tartu: Akadeemilise Emakeele Seltsi Kirjastus.

Niemi, A. R. 1927. Suomen Kansan Vanhat Runot II. Aunuksen, Tverin-ja NovgorodinKarjalan runot. Helsinki: Suomalaisen Kirjallisuuden Seura.

Peebo, Jaak. 1989. Eestikeelse Piibli ühe eelkäija sõnavarast. Keel ja Kirjandus 32(12). $720-726$.

Peegel, Juhan. 1970. Üks keelearheoloogiline killuke: kabu. Keel ja Kirjandus 13(11). 671-672.

Pino, Veera \& Vaike Sarv. 1981. Setu surnuitkud I. Tallinn: ENSV TA Keele ja Kirjanduse Instituut.

Päss, Elmar. 1927. Lutsi-Eesti parmumatuse-laulu vastastikusest suhtumisest. Album M. J. Eiseni 70. sünnipäevaks, 72-103. Tartu. 
Remmel, Mari-Ann (ed.). 1997. Rahva ja luule vahel. Kogumispäevikuid aastaist 18781996. Eesti kirjandusmuuseumi aastaraamat (Paar sammukest eesti kirjanduse uurimise teed XIV). Tartu.

Rüütel, Ingrid. 1970. Vadja pulmalauludest ja nende suhetest eesti laulutraditsiooniga. Läänemeresoomlaste rahvakultuurist, 64-93. Tallinn.

Rüütel, Ingrid. 1971. Eesti uuema rahvalaulu varasemast arengujärgust. In Ottilie Kõiva (ed.), Paar sammukest eesti kirjanduse uurimise teed VII, 11-100. Tartu: Eesti NSV Teaduste Akadeemia.

Rüütel, Ingrid. 2001. Tipologija estonskih runitsheskih napevov v pribaltiisko-finskom i baltskom kontekste. In Tõnu Seilenthal, Anu Nurk \& Triinu Palu (eds.), Congressus nonus Internationalis Fenno-ugristarum. Pars VII. Dissertationes sectionum: Folkloristica \& Ethnologi, 215-226. Tartu.

Salve, Kristi. 1984. Sanditamine liivlastel. In Eduard Ertis, Ottilie Kõiva, Ellen Liiv \& Rudolf Põldmäe (eds.), Eesti rahvaluule aspekte (Paar sammukest eesti kirjanduse uurimise teed X), 83-119. Tallinn.

Salve, Kristi \& Ingrid Rüütel. 1989. Põhja-Tartumaa regilaulud I. Töö- ja tavandilaulud. Tallinn: ENSV TA Keele ja Kirjanduse Instituut.

Salve, Kristi. 2000. Toone tare. Setu itkude žanridevahelistest ja geograafilistest seostest. In Mare Kõiva, Kristi Salve, Ülo Tedre (eds.), Tagasipöördumatus. Sõnad ja hääl, 55-72. Tartu: Eesti Kirjandusmuuseum.

Salve, Kristi. 2015. Oma nägu ja võõras võõp. In Madis Arukask (ed.), Üleaedsed, 285-309. Tartu: Ilmamaa.

Salve, Kristi \& Vaike Sarv. 1987. Setu lauludega muinasjutud, 14-15. Tallinn: ENSV TA Keele ja Kirjanduse Instituut.

Sarv, Vaike. 1999. Setu alade jaotus rahvaviiside põhjal. In Karl Pajusalu \& Tõnu Tender (eds.), Õdagumeresoomõ veeremaaq. Läänemeresoome perifeeriad (Publications of Võro Institute 6), 298-307. Võru: Võro Instituut'.

Setälä, Emil Nestor \& Kala, Juho Heikki. 1935. Näytteitä äänis- ja keskivepsän murteista (Suomalais-Ugrilaisen Seuran Toimituksia 100). Helsinki: SuomalaisUgrilainen Seura.

Tampere, Herbert. 1956. Mõningaid eestlaste etnilise ajaloo küsimusi suulise rahvaloomingu valgusel. In Moora, Harri (ed.), Eesti rahva etnilisest ajaloost, 255-277. Tallinn: Eesti Riiklik Kirjastus.

Tampere, Herbert. 1960. Eesti rahvalaule viisidega II. Tallinn: Eesti Riiklik Kirjastus.

Hurt, Jakob. 1904. Setukeste laulud: Pihkva-Eestlaste vanad rahvalaulud ühes Räpina ja Vastseliina lauludega I. Helsinki: Soome Kirjanduse Selts.

Tarto-ma-kele Laulu-Ramat. 1881. Tartu: H. Laakmann.

Tedre, Ülo. 1998. Oskar Kallas folkloristina. In Oskar Kallas. Artikleid Oskar Kallase elust ja tööst, 131-188. Tartu.

Tedre, Ülo. 2000. Itku relikte eesti pulmakombestikus. In Mare Kõiva, Kristi Salve, Ülo Tedre (eds.), Tagasipöördumatus. Sõnad ja hääl, 229-237. Tartu: Eesti Kirjandusmuuseum.

Vaba, Lembit. 1997. Uurimusi läti-eesti keelesuhetest. Tallinn, Tampere: Eesti Keele Instituut, Tampereen Yliopiston suomen kielen ja yleisen kielitieteen laitos. 
Vaba, Lembit. 2001. Doktoritöö läti eestlastest. Retsensioon: Marjo Mela. Latvian virolaiset. Historia, kieli ja kulttuuri. Helsinki, SKS, 213 lk. Keel ja Kirjandus 47(10). 735-739.

Valk, Heiki. 1996. Aegadest ja ajatunnetusest Setomaal. Palve, vanapatt ja pihlakas. (Vanavaravedaja 4.), 59-92. Tartu: Tartu Ülikooli arheoloogia kabinet.

Vissel, Anu. 1988. Eesti karjaselaulud II. Võrumaa ja Tartumaa karjaselaulud. (Ars Musicae Popularis 7). Tallinn: ENSV TA Keele ja Kirjanduse Instituut.

Vītoliņš, Jēkabs. 1958. Latviešu tautas mūzika I. Darba dziesmas. Izlase. Rīga

Vītoliņš, Jēkabs. 1968. Latviešu tautas mūzika. Kāzu dziesmas. Rīga

Vītoliṇš, Jēkabs. 1973. Latviešu tautas mūzika. Gadskārtu ieražu dziesmas. Rīga

Voolaine, Paulopriit. 1925. Lutsi maarahvas 1925. a. Eesti Kirjandus 19(9). 372-379.

Voolaine, Paulopriit. 1927. Koiva maarahvas. Album M. J. Eiseni 70. sünnipäevaks, 164-174. Tartu.

Västrik, Ergo-Hart. 1998. Vadja kohapärimus I. Inimasustusega seotud paigad ja kinnismuistised. In Karl Pajusalu \& Jüvä Sullõv (eds.), Õdagumeresoomõ väikuq keeleq. Läänemeresoome väikesed keeled: konverents Kurgjärvel rehekuu 23.-25. 1997 (Võro Instituudi toimetised 4), 132-150. Võru: Võro Instituut.

Õunapuu, Pärja. 1998. O. Kallas ja ERM. In Aru, Krista \& Sirje Olesk (eds.), Oskar Kallas. Artikleid Oskar Kallase elust ja tööst, 77-98. Tartu: Eesti Kirjandusmuuseum.

Kokkuvõte. Kristi Salve: Tähelepanekuid Lutsi maarahva suulisest pärimusest. Artiklis on vaadeldud Lutsi maarahva vaimset kultuuri, püüdes selgust tuua keelesaare kujunemisloosse. Ajaloolised jutud „Rootsi“ päritolust viitavad küll Lõuna-Eestile, kuid sellised jutud on levinud ka aladel, mis pole Rootsi võimu alla kuulunudki. Lutsi kristlik pärimus lähtub Eesti kirikukeelest ja -kirjandusest. Lutsi itkud või itkulaadsed laulud on omapärased, erinedes setu itkudest, aga ka Lõuna-Eesti itkulaadsetest vaeslapselauludest. Töö- ja tavandilaulud, samuti jutustavad laulud seostuvad nii Võrumaa kui ka Setumaa traditsiooniga. Juba Oskar Kallase kogus on silmapaistvalt palju lastele mõeldud laule ja lugemisi, lühikesi (pilke)salmikesi ja muud perifeerset rahvaluule ainest. Hilisemates kogudes nende osakaal suureneb. Silmapaistev on läti laulude mõju alates otsestest tõlgetest kuni tekstideni, milles genuiinne ja laenuline segunevad. Ilmselt on Lutsi traditsiooni mõjutanud ka naabruses elavad slaavi rahvad. Võrdluses teiste vanade eesti keelesaarte, aga ka Tveri karjalaste rahvaluulega hakkab silma mõndagi ühist, kuid samas ka erinevat.

Märksõnad: folklooriliigid, itkud, regilaulud, kristlik pärimus, läänemeresoome, lõunaeesti, Lutsi, läti mõju 